\title{
Customers' Socio-economic Characteristics and the Perception of Service Quality of Bahraini Commercial Banks
}

\author{
Dr. Wathek S Ramez \\ College of Business \& Finance, AHLIA University \\ Manama, Bahrain \\ Tel: 973-1729-8941Ｅ-mail: watheqramez@hotmail.com
}

Received: March 9, $2011 \quad$ Accepted: April 22, $2011 \quad$ Published: October 1, 2011
doi:10.5539/ijbm.v6n10p113 $\quad$ URL: http://dx.doi.org/10.5539/ijbm.v6n10p113

\begin{abstract}
This study aims: to apply the SERVQUAL instrument to evaluate the service quality of commercial banks of Bahrain, and to investigate the relationship between customers' socio- demographic characteristics and the overall service quality and its dimensions. Based on a questionnaire survey of 195 customers, the results indicate that SERVPERF scale explains more of the variance in service quality than SERVQUAL scale. Three - factor solutions were produced, the first factor includes: reliability, responsiveness and assurance dimensions, which have the largest influence on the overall service quality. In addition, no significant relationships were found between customer's socio- demographic characteristics and the overall service quality. However, significant differences were observed in the perceptions of customers' nationality and duration of experience groups and the reliability and empathy dimensions.
\end{abstract}

Keywords: SERVQUAL/SERVPERF, Customers' socio-demographic characteristics, Commercial banks Research, Bahrain

\section{Introduction}

Service quality has become a major topic of concern to academic researchers and professional managers for the past two decades. Service marketing literature reveals that nineteen service quality models have been developed during the period (1984-2003), (Seth, Deshmukh and Vrat, 2005). The primary goal of these models is to offer managers insights into the components of service quality for improving their organizations' offering.

The service quality model "SERVQUAL' is the most famous of these models. It is based on the assumption that service quality is a function of differences (gaps) between customers' expectations and perceptions along five quality dimensions: reliability, responsiveness, tangibles, assurance and empathy, (Parasuraman et al. (1985, $1988,1991)$. Consequently, improving the customers' perceptions of service quality offers a firm an opportunity to differentiate it's self and gain a competitive advantage in the market (Wang et al, 2003). This is certainly true in the banking industry around the world. In the case of Bahrain, the banking sector consisted of 376 banks and financial institutions at the end of 2006 (25 retail banks, 86 wholesale banks, 2 specialized, 34 representative offices and .....), (Central Bank of Bahrain, 2006). The role of banking sector of Bahrain is expected to increase after the opening of the financial harbor.

The purpose of this research is to: (1) apply SERVQUAL and/ or SERVPERF instrument for evaluating the service quality of commercial banks of Bahrain. (2) assess the relative importance of service quality dimensions according to a banks' customers. (3) examine the relationship between customers' socio- demographic characteristics and the overall service quality of Bahraini commercial banks.

\section{The importance of the present study}

The need for this study has emerged from two facts: (1) Although there have been many studies carried out for measuring the service quality based on the SERVQUAL model in developed and some developing countries, a limited number of similar research has been undertaken in the Arabic countries during the last two decades. In the state of Bahrain, in particular, no attempt has been made to apply the SERVQUAL model for evaluating the service quality in any part of the service industry. (2) The state of Bahrain is a member of the GCC (Gulf 
Co-operation Council) which includes Kuwait, Saudi Arabia, United Arab Emirates, Qatar and Oman. All these countries have unique socioeconomic and legal characteristics which make the applicability of SERVQUAL model differ from country to country. Bahrain has been considered one of the major financial centers in the region and the Middle East since the nineteen seventies. However, it is facing growing competition from other financial centers in Dubai and Saudi Arabia. Managers of commercial banks in Bahrain are keen to maintain their superiority in the financial industry. Enhancing customers' perceived quality of the banks' offering is the concern of management in Bahrain.

\section{Literature survey}

Parasuraman et al. $(1985,1988,1991)$ carried out a sequence of research resulting in development of the service quality model "SERVQUAL ", which is based on customers' expectations and perceptions for five dimensions, consisting of 22 scaled items of service quality. Many researchers have applied the SERVQUAL instruments, with some modification or additional operational measurements, to measure service quality in the banking industry.

Relating to the state of Bahrain, (Metawa and Almossawi, 1998) designed a 14 items questionnaire to investigate customers' reactions to the two main Islamic banks. The results of chi- square test, indicated that there were significant relationships between customer' ages, education groups, and the usage of current accounts and ATM cards. Significant relationships were also observed between customers' income groups and the usage of "current account, money orders/ drafts and investment accounts". In addition, the study revealed significant relationships between customers, ages, education and income groups and the relative importance of selection criteria of the Islamic banks, which are mainly in favor of the "adherence to Islamic principles", followed by "rate of return". In general, the study results showed that customers were generally satisfied with the mostly used products / services, which were investment accounts and the service delivery system.

Within the Arabic Gulf Region, (Al- Tamimi and Al- Amiri, 2003) found a positive and statistically significant relationship between SERVQUAL dimensions, in particular empathy and tangible dimensions; and overall service quality of the UAE Islamic banks (Dubai and Abu Dhabi Islamic banks). In addition, the results indicated no significant differences in the service quality of the two banks based on the customer's gender and nationality, while the opposite results were observed, based on customer's ages, education and the number of years with the banks.

Jannadi and Al- Saggaf (2000) applied the modified SERVQUAL instrument (merging statements 5 and 8 because they appeared to be similar) to measure customers' perceptions of electrical service quality provided by the SCECO company in the Eastern province of Saudi Arabia. The results of descriptive analysis indicated that the company's performance was acceptable to all customer groups. The company rated high in "Tangible" dimension but low in the 'responsiveness and reliability" dimensions. However, commercial, secondary education level and (41-50) age customer groups rated the company's service quality lower than other customer groups did.

Within the context of Arabic countries, one of the earliest studies in the field of service quality was performed by El. Sahan (1994). He found first that the SERVPERF model was better than the SERVQUAL model for predicting the service quality of commercial banks in Alexandria. Consequently, reliability, responsiveness and tangibles dimensions were the major considerations of the customers' evaluation of overall service quality.

Regarding the studies in developed countries, Roig et al (2006) analyzed the dimensionality of perceived values in the Spanish banking sector. The GLOVAL scale of measurement was adopted in the survey covering a total of 200 customers. The results showed that the perceived value is made up of six dimensions: functional values of the establishment, personnel contact, services, price, emotional and social values.

Baumann, et al. (2007) investigated the predictive power of the SERVQUAL dimensions, relative to the affective attitude and overall satisfaction, on customer loyalty in retail banking of Australia. The results showed that customers' willingness to recommend a bank to others is best predicted by affective attitudes, overall satisfaction and empathy dimension of SERVQUAL. Short term intentions to remain with the bank are best predicted by overall satisfaction and responsiveness, while long term customers' intentions to remain with the bank are best predicted by overall satisfaction, affective attitudes and empathy. In general, the study proved that adding affective attitudes and overall satisfaction to the SERVQUAL dimensions can enhance the explanatory power of the model.

In relation to developing countries, Yavas, Bilgin and Shemwell (1997) investigated the effect of service quality dimensions on consumer satisfaction, complaint behavior and commitment within the context of the Turkish 
banking environment. The results indicated that tangible, responsiveness and empathy dimensions are the most significant predictors of consumer satisfaction. In addition, tangible and responsiveness dimensions are the most significant antecedents of commitment with the bank, while empathy is the only dimension of all that has a significant relationship with complaint behavior.

Glaveli et al. (2006) examined the differences in customers' perceptions toward service quality of the retail banking industry in five Balkan countries (Greece, Bulgaria, Albania, FYROM and Serbia). Applying Bank Service Quality (BSQ) measurement for collecting the data, the study found that Greek customers have the highest level of perception toward service quality. In addition, there are differences and similarities among customers of these counties toward the relative importance of the service quality dimensions. In general, effectiveness, price and reliability were perceived the most important factors in all five Balkan countries, while "access" factor was the least important factor.

Arasli, Katircioglu and Samadi (2005) made comparisons between Turkish and Greek customers' evaluations of service quality of commercial banks in Cyprus. Using the SERVQUAL instrument, the results indicate the customers' expectations on both sides of the island, fell below their perceptions of service quality, especially the empathy dimension. Assurance dimension has the highest affect on overall customers' satisfaction in both areas, which, in turn, has a positive relationship with customers' word- of- mouth recommendations.

Within the contest of globalization of the banking industry, Malhotra et al. (2005) examined and compared customers' perceptions of service quality dimensions between the USA as a developed country and the developing countries of India and the Philippines. The initial framework of Parasuraman et al.'s service quality model $(1985,1988)$, which consisted of ten dimensions, in association with conventional economic and socio-cultural factors, were used to collect the data. The results indicate that there are significant differences between developed and developing countries, in relation to service quality dimensions. On the other hand, Yavas and Benkenstein (2007) found that the underlying configurations of service quality perceptions could be divided into three factors for Turkish and German bank customers. In addition, a strong congruence between both groups was obvious. Thus, the study concludes that the same measurement of service quality can be applied to different cultures.

\subsection{SERVQUAL Instrument}

Parasuraman et al. (1991). SERVQUAL framework has been administrated into two sections: the first section is concerned with measuring customers' expectations and the second one is specified for measuring the perceptions. Each section includes 22 items representing the five dimensions of service quality.

\subsection{SERVQUAL Criticisms}

In spite of the wide application of SERVQUAL framework for measuring the service quality, some scholars have raised some concern about the conceptualization and operationalization issues of the model:

Parasuraman et al. $(1985,1988,1991)$ proposed their model based on the confirmation/ disconfirmation theory $(\mathrm{SQ}=\mathrm{P}-\mathrm{E})$. Since then, many marketing scholars have argued that neither disconfirmation theory nor expectation have any effect on customer satisfaction, (Cronin and Taylor, 1994; Teas, 1994; Buttle, 1996). Instead, customer's perception have been only recommended for measuring service quality (SERVPERF) since it is a good indicator of customers' satisfaction levels (Cronin and Taylor, 1992; Cadott, Woodruff and Jenkins, 1987; Lee, Lee, \& Yoo, 2000; Luk and Layton, 2004; Baumann et al., 2007).

On the other hand, many scholars have questioned the universality and dimensionality of SERVQUAL instrument. They argued that SERVQUAL instrument could not be a generic measure that could be applied to all services, instead it needs to be customized to fit the nature of a specific service (Carman, 1990; Buttle, 1996; Mels et al., 1997). To avoid such weaknesses, other researchers proposed different structural models (Gronroos, 1984; Lehtinen and Lehtinen, 1985; Mels et al., 1997; Svensson, 2006). Furthermore, other researchers questioned the validity of SERVQUAL model, namely convergent and discriminant validity, (Cronin and Taylor, 1992; Teas, 1993; Nyeck et al., 2002).

Coulthard (2004) provides a comprehensive review for the service quality research since (1998). She concluded that further research is required to control or inhibit the conceptual, methodological and interpretative biases of SERVQUAL instrument. Regardless of the criticism toward the validity and reliability of SERVQUAL instrument, Buttle (1996) argued that it remains a useful instrument for measuring service quality.

\section{Research Methodology}

4.1 Research Hypotheses 
To achieve the purpose of this study, the following hypotheses were developed:

H1: there are no significant differences in the perceptions of customer groups of Bahraini commercial banks towards the five dimensions of service quality, (tangibles, reliability, responsiveness, assurance and empathy).

H2: there are no significant differences between customer's gender groups towards the perceived service quality of Bahraini commercial banks.

H3: there are no significant differences between customer's age groups towards the perceived service quality of Bahraini commercial banks.

H4: there are no significant differences between customer's education groups towards the perceived service quality of Bahraini commercial banks.

H5: there are no significant differences between customer's nationality groups towards the perceived service quality of Bahraini commercial banks.

H6: there are no significant differences between customer's years of experience groups towards the perceived service quality of Bahraini commercial banks.

Some statistical techniques were used to analyze the data generated by the questionnaire survey, such as: descriptive analysis, factor analysis. To test the study hypotheses, regression and ANOVA analyses were employed.

\subsection{Instrument design}

SERVQUAL instrument was used to measure the perceived service quality, as was proposed by Parasuraman et al. (1988). The instrument was first translated into Arabic, as the majority of Bahraini citizens are Arabic. Then, the translated version was submitted to a number of instructors of the Business Administration College at the University of Bahrain, for revision. Their respected and remarkable suggestions about the phrasing and wording of the translated instrument were reviewed and undertaken by the researcher. Later, an instructor at the English Department compared the original instrument with the translated Arabic version, for final examination. The final Arabic version of the instrument became ready after an instructor at the College of Arts checked the wording and the grammar of the language.

Both versions of the instrument include four sections: the first section covers the demographic characteristics of the respondents such as: gender, age, education.... The second and third sections contain questions about the respondents' expectations and perceptions to the five dimensions of service quality respectively. These five dimensions, that consist of 22 items for each of the expectation and perception part, are measured by seven-point Likert scale ranging from " Strongly Disagree $=1$ " to " Strongly Agree $=7$ ". The fourth section includes five statements that are related to the relative importance of the service quality dimensions, measured by allocating 100 points to them. Each statement reflects the contents of each dimension, without naming the specific dimension.

\subsection{Sampling and Data Collection}

A convenience sampling of bank customers was conducted during the first three months of 2008. Administrated questionnaires were distributed personally to the bank customers in Manama, the capital of Bahrain. People who have at least one year of relationship with their commercial banks were only intercepted by interviewers at different geographical locations such as shopping centers, banks and business offices. 210 respondents agreed to participate in the survey, 15 questionnaires were eliminated at the preliminary evaluation stage for inconvenience or incomplete answers. The remaining 195 questionnaires were considered qualified to be included in further statistical analysis. They represent a $(92.857 \%)$ response rate.

\section{Statistical Results and Discussion}

\subsection{Respondents' demographic Characteristics}

Table (1) shows that $52.3 \%$ of the respondents out of the total study samples (195) were male and $47.7 \%$ were female. The majority of those participants were young or middle aged people, $34.359 \%$ for the age $(20-29)$ years, and $28.205 \%$ for the age $(30-39)$ years and $27.693 \%$ of them were between (40- 49) years of age. In addition, they were highly educated people, $63.077 \%$ of them had a University (B. Sc) degree and $25.641 \%$ had diplomas. They were at different occupational levels, ranging from Executive / Manager (15.385\%) to housewife $(12.821 \%)$ and unemployed workers $(3.077 \%)$. Regarding the nationality of participants, the majority of them were Bahrainis $(81.539 \%)$ out of the total samples (195). 


\subsection{Validity and reliability tests}

First, to test the fitness of the entire sample for conducting factor analysis, the Kaiser- Meyer - Olkin measure was calculated. The KMO value is .934 and the Bartlet sphere test is also significant at $p<0.001$, Table. 4 . These results suggest that factor analysis can be used in this study.

To test the internal consistency of the SERVQUAL scale that is adopted in the present, the overall total scale and all dimensions (tangible, reliability ........ empathy) in the Expectation, Perception and Gap sections were subjected to reliability assessment.

The values of Cronbach's coefficient alpha for the total scale and for each dimension in the expectation, perception and gap sections exceed the minimum standard (0.70) that was recommended by Churchill (1979). The lowest value of all can be observed in the "Assurance" dimension of gap section (.714), Table.2. These figures indicate a good internal consistency among items of each individual dimension, and thus our scale can be considered quite reliable.

\subsection{Results of Factor Analysis}

According to the procedures of Parasuraman et al. studies, the gap scores were calculated by subtracting each respondent's perception score for each item from his/ her own expectation score for that item. A factor analysis was performed on both the Gap score (SERVQUAL) and the SERVPERF scale using varimax rotation. Factors with eigenvalues greater than 1.0 and items that have factor loadings equal or greater than .5 , were retained. In addition, items that show cross-loading greater than .5 on more than one factor were dropped since they make the interpretation of the factors difficult and less precise. These procedures on the SERVQUAL scale resulted in five-factor solution that explained a total of $61.002 \%$ of the variance in service quality. This figure is less than the $62 \%$ level reported in Parasuraman et al.'s studies by $.998 \%$. On the other hand, reviewing the loadings of all items in Table. 3 reveals that 9 items have to be dropped. Specifically, item 19 is deleted because it has loading less than .5. Items 2 and 9 on factor 4 have to be dropped since they had more than .5 factor loading on other factors ( 2 and 1 respectively). Although, the factor loadings of items 14, 15, 16 and 17 of the assurance dimension were greater than .5 , they are split over four factors and thus have to be eliminated to avoid unclear dimensionality. Finally, item 18 was loaded with factor 5 instead of factor 2, and thus it has to be dropped. Consequently, three clean factors with thirteen items were produced by factor analysis on gap score scale, which is inconsistent with the findings proposed by Parasuraman et al.'s studies $(1988,1991)$.

On the other hand, conducting factor analysis on the SERVPERF scale resulted into three - factor solution which explains $65.166 \%$ of the variance in service quality, Table.4. Factor 1 includes three dimensions of service quality which are reliability, responsiveness and assurance, while factors 2 and 3 include the remaining two dimensions: empathy and tangibles respectively. The results show high correlation between the items of the first three dimensions of service quality. Nevertheless, items 12 and 13 of the responsiveness dimension have to be dropped from further analysis since they were associated with factor 2 . The results of this study support the findings of other studies (e.g. Cornin and Taylor, 1992) that have indicated that the SERVPERF scale captures more of the variance in service quality than the SERVQUAL scale. For reasons mentioned in the literature survey section and for the study results, the SERVPERF scale will be employed in the further analysis.

\subsection{Hypotheses Testing}

\subsubsection{Hypothesis one}

Customers of Bahraini commercial banks were asked to allocate 100 points over the five dimensions of service quality, to measure the priority of each one. Consequently, the respondents showed differences in their assessment of the relative importance of each dimension, Table 5 . The reliability dimension received the highest average points .238 , followed by the responsiveness dimension with .208 average points, whereas the empathy dimension rated the least importance of all with .161 average points.

The weighted mean scores for the overall perception of service quality and its five dimensions indicate that respondents highly evaluated the reliable, tangible and responsiveness dimensions of service quality of commercial banks in Bahrain, Table. 5.

To predict the impact of the relative importance of the five dimensions on the customers' evaluation of overall service quality, linear regression analysis was performed, where the weighted mean of overall service quality as a dependent variable and the weighted means of service quality dimensions as the independent variables. The value of $\mathrm{R}$ square (0.545) reveals that the five independent variables explain $54.5 \%$ of the variation in the dependent variable, Table. 5. In addition, the results indicate that reliability is the most important dimension of all with a coefficient value of .378 , and responsiveness was the second most important (.363), while assurance 
comes in the third position. These findings support the conclusions reached by most researchers in the field of service quality, which agree that the reliability dimension is the most crucial factor influencing service quality, (Parasuraman et al., 1988; AL. Tamimi and AL. Amiri, 2003). Based on these findings and the high score of F (45.354), the first null hypothesis is rejected.

\subsubsection{Hypothesis two}

The results of ANOVA analysis shows that there are no significant differences in the perception of males and females groups towards the overall service quality and its five dimensions as the significant level are over the 0.05 percent, (Table. 6 ). Consequently, the study accepts the null hypothesis.

\subsubsection{Hypothesis three}

Respondents' age groups did not show any differences in their perception of overall service quality neither its dimensions, (Table. 7). Such results can be clarified on the ground that the majority of the respondents were mature people and thus they are more rational than other customers' groups in the evaluation of service quality, provided by their banks. Consequently, the study confirms the null hypothesis.

\subsubsection{Hypothesis four}

Table 8 shows no significant differences in the perception of service quality of Bahraini commercial banks between different education levels of respondents. The results can be justified on the basis that the majority of the study samples are concentrated in the diplomas and B.Sc degree groups (Table. 1), and thus the study confirms the null hypothesis.

\subsubsection{Hypothesis five}

Table 9 indicates that neither Bahraini and nor non Bahraini respondents differed in their perception of overall service quality. However, regarding the dimensions of service quality, significant differences between local and expatriate respondents were found in the case of reliability and empathy dimensions as the significant levels are below 0.05 percent for both dimensions. Such results can be justified on the basis that non Bahraini customers, in general, are living in Bahrain for a short period of time, and therefore they tend to do business with those banks that can be trusted and sympathetic to their needs.

\subsubsection{Hypothesis six}

The duration of a respondent's experience with a bank seems to have no significant affect on their perceptions of overall service quality of commercial banks in Bahrain. However, a significant difference between respondent's groups is only observed in the case of the empathy dimension, while non significant results are clear in the overall service quality and the other dimensions, (Table. 10). Such results can be expected in the state of Bahrain since the majority of people have high moral values and friendly personalities. The results do not support this hypothesis.

\section{Conclusion and managerial application}

The findings of this study support the hypothesis that performance scores can offer better measurement results than gap scores. The SERQUAL scale explains $61.002 \%$ of the cumulative variance in the overall service quality, compared with $65.166 \%$ by the SERVPERF scale. On the other hand, factor analysis for SERVQUAL construct produces five factors, but after dropping the cross loading items over more than one factor ...., three clean factors that include thirteen items remained. Although, the SERVPERF construct results in a three factorsolution, one factor covers three dimensions: reliability, responsiveness and assurance. The totals of twenty items were valid. The study findings demonstrate that the overall service quality of banking industry may not be a function of the five dimensions as originally suggested by Parasuraman et al. studies.

Regarding the importance of service quality dimensions, it appears that Bahraini customers rated the reliability dimension the most important of all with average points .238 , followed by responsiveness (.208) and tangible dimension (.204), whereas Empathy dimension rated at the least important. Meanwhile, the results of linear regression show that the SERVPERF dimensions explains $54.5 \%$ of the variation in the overall service quality. Reliability is the most important influencer of overall service quality with a coefficient score .378 , followed by the responsiveness dimension (.363), while assurance is third.

The findings of this study reflect the following managerial implications: First, systematic assessment of customers' perceived service quality is a vital element to formulate the service marketing strategy over time. Such processes will enable the managers of a given bank to identify the points of strength and weakness, relative to competitors, and consequently investing the available resources in the dimensions that consolidate a bank's competitive position. Second, managers and staff of Bahraini commercial banks should work together to provide 
customers with reliable services, prompt responses and assured procedures. By doing so, a bank will enhance their customers' perceptions of the overall service quality. Third, bank managers should consider their customers' socio- demographic characteristics to redesign the operational system and recruit qualified people to offer a better and consistent level of service quality.

Regardless of the contribution to the topic of service quality, the present study suffers two points of limitation. First, convenience sampling technique was mainly used to select the study respondents. Customers of Bahraini commercial banks were only intercepted, while customers of Islamic banks and other financial institutions were not considered. Such procedure restricts the representation of all customers of banking industry in Bahrain, and thus will affect the generalization of the study findings. Second, the study investigated customers' expectations and perceptions toward the service quality of the banking sector, while other service sectors, such as airlines and hotels in Bahrain, were not covered. Therefore, further empirical researches are needed to measure the overall service quality and its relationship with customers' satisfaction and behavioral intentions in different sectors of the service industry.

\section{References}

AL-Tamimi, H.A., \& AL-Amiri, A. (2003). Analysing service quality in the UAE Islamic banks. Journal of Financial service Marketing, 8(2), pp. 119-132. http://dx.doi.org/10.1057/palgrave.fsm.4770112

Arasli, H., Katircioglu, S.T., \& Mehtap-Smadi, S. (2005). A comparison of service quality in the banking industry. International Journal of Bank Marketing, 23(7), pp. 508-526. http://dx.doi.org/10.1108/02652320510629881

Baumann, C., et al. (2007). Prediction of attitude and behavioral intentions in retail banking. International Journal of Bank Marketing, 25(2), pp. 102-116. http://dx.doi.org/10.1108/02652320710728438

Bitner, M.J. (1990). Evaluating service encounters: the effects of physical Surroundings and employee responses. Journal of Marketing, 54(2), pp. 69-82. http://dx.doi.org/10.2307/1251871

Buttle, F. (1996). SERVQUAL: review, critique, research agenda. European Journal of Marketing, 30(1), pp. 8-32. http://dx.doi.org/10.1108/03090569610105762

Cadott, E., Woodruff, R., \& Jenkins, R. (1987). Expectations and norms in Models of consumer satisfaction. Journal of Marketing Research, 24 (3), pp. 305-314. http://dx.doi.org/10.2307/3151641

Carman, J. M. (1990). Consumer Perceptions of Service Quality: An Assessment of the SERVQUAL Dimensions. Journal of Retailing, 66(1), pp.33- 55.

Central Bank of Bahrain. Annual Report. (2006).

Coulthard, L. J. (2004). Measuring service quality: A review and critique of research using SERVQUAL. International Journal of Market Research, 46(4), pp. 479-497.

Churchill Jr, G.A. (1979). A paradigm for Developing Better Measures of Marketing Constructs. Journal of Marketing Research, 16(1), pp. 64 - 73. http://dx.doi.org/10.2307/3150876

Cronin Jr. J.J., and Taylor, S.A. (1992). Measuring service quality: a reexamination and extension. Journal of Marketing, 56(3), pp. 55 - 68. http://dx.doi.org/10.2307/1252296

Cronin Jr. J.J., and Taylor, S.A. (1994). SERVPERF versus SERVQUAL: reconciling performance-based and perception-minus-expectation measurement of service quality. Journal of Marketing, 58(1), pp. 125-31. http://dx.doi.org/10.2307/1252256

El Sahan, Farid. (1994). The Perceived Quality of Banking Services: An Empirical Study for Testing its Determinates and the Models used in Measuring it. Faculty of Commerce Magazine for Scientific Researches Alexandria University, 2(31).

Glaveli, N., et al. (2006). Bank service quality: evidence from five Balkan Countries. Managing Service Quality, 16(4), pp. 380-394. http://dx.doi.org/10.1108/09604520610675711

Gronroos, C. (1984). A Service Quality Model and Its Marketing Implications. European Journal of Marketing, 18(4), pp. 36-44. http://dx.doi.org/10.1108/EUM0000000004784

Jannadi, Osama. A., \& Al- Saggaf, Hammed. (2000). Measurement of Quality in Saudi Arabian Service Industry. International Journal of Quality \& Reliability Management, 17(9), pp. 949-955.

Leblanc, G., and Nguyen, N. (1988). Customers' perception of Service Quality in Financial Institutions. International Journal of Bank Marketing, 6(4), pp. 7-18. http://dx.doi.org/10.1108/eb010834 
Lehtinen, U., and Lehtinen, J.R. (1985). Service Quality: a Study of Quality Dimensions. Paper read at Second World Marketing Congress, University of Stirling, Scotland.

Lee, H., Lee, y., \& Yoo, D. (2000). The determinants of perceived service Quality and its relationship with satisfaction. Journal of Services Marketing, 14(3), pp. 217-231. http://dx.doi.org/10.1108/08876040010327220

Luk, S. T., \& Layton, R. (2004). Managing both Outcome and Process Quality is Critical to Quality of Hotel Service. Total Quality Management, 15(3), pp. 259-278. http://dx.doi.org/10.1080/1478336042000183415

Malbotra, N.K., et al. (2005). Dimensions of service quality in developed And developing economies: multi-country cross-cultural comparisons. International Marketing Review, 22(3), pp.256-278. http://dx.doi.org/10.1108/02651330510602204

Mels, G., Boshoff, C., \& Nel, D. (1997). The Dimensions of Service Quality: The Original European Perspective Revisited. The Service Industries Journal, 17(1), pp. 173-189.

Metawa, S.A., and Almossawi, M. (1998). Banking behavior of Islamic Bank customers: perspectives and implications. International Journal of Bank Marketing, 16(7), pp.299-313. http://dx.doi.org/10.1108/02652329810246028

Nyeck, S., et al. (2002). 10 Years of Service Quality Measurement: Reviewing The Use of The SERVQUAL Instrument. 31 conference dela European Marketing Association, 7(13), pp.101-107.

Nunnally, J. C. (1978). Psychometric Theory, (3 ${ }^{\text {rd }}$ ed). New York: McGraw-Hill.

Parasuraman A., Zeithaml, V.A., \& Berry, 1. 1. (1985). A Conceptual Model of Service Quality and its Implications for Future Research. Journal of Marketing. 49(4), pp. 41- 50.

Parasuraman A., Zeithaml, V.A., \& Berry, 1. 1. (1988). SERVQUAL: Multiple- Item Scale for Measuring Consumer Perception of Service Quality. Journal of Retailing, 64(1), pp. 12-40.

Parasuraman A., Zeithaml, V.A., \& Berry, 1. 1. (1991). Refinement and Reassessment of the SERVQUAL Scale. Journal of Retailing, 67(4), pp.420- 450.

Roig, J.C. et al. (2006). Customer perceived value in banking services. International Journal of bank Marketing. 24(5), pp. 266-283. http://dx.doi.org/10.1108/02652320610681729

Seth, N., Deshmukh, S.G., \& Vrat, P. (2005). Service quality models: a review. International Journal of Quality \& reliability Management, 22(9), pp.913- 949. http://dx.doi.org/10.1108/02656710510625211

Svensson, G. (2006). The interactive of service quality. European Business Review, 18(3), pp. 243-257. http://dx.doi.org/10.1108/09555340610663755

Teas, R.K. (1993). Expectations performance evaluation and consumers' Perceptions of quality. Journal of Marketing, 57(3), pp.18-34. http://dx.doi.org/10.2307/1252216

Teas, R.K. (1994). Expectations as a comparison standard in measuring service Quality: an assessment of reassessment. Journal of Marketing, 58(1), pp. 132-139. http://dx.doi.org/10.2307/1252257

Wang, Y, Lo, H., and Hui, Y.V. (2003). The Antecedents of Service Quality and Product Quality and their Influences on Bank Reputation: Evidence from Banking Industry in China. Managing Service Quality, 13(1), pp. 72-83. http://dx.doi.org/10.1108/09604520310456726

Yavas, U., \& Benkenstein, M. (2007). Service quality assessment: a comparison of Turkish and German bank customers. Cross Cultural Management International Journal, 14(2), pp. 161-168. http://dx.doi.org/10.1108/13527600710745769

Yavas, U., Bilgin, Z., \& Shenwell, D.J. (1997). Service quality in the banking sector in an emerging economy: a consumer survey. International Journal of Bank Marketing, 15(6), pp. 217-223.

Zeithaml, V.A., Berry, L.L., and Parasuraman, A. (1996). The Behavioral Consequences of Service Quality. Journal of Marketing, 60(April), pp.2-22. http://dx.doi.org/10.2307/1251929 
Table 1. Demographic Characteristics of Respondents

\begin{tabular}{|c|c|c|}
\hline Characteristics & Frequency & $\%$ \\
\hline \multicolumn{3}{|l|}{ Gender: } \\
\hline Male & 102 & 52.3 \\
\hline Female & 93 & 47.7 \\
\hline \multicolumn{3}{|l|}{ Age: } \\
\hline Under 20 years & 4 & 2.051 \\
\hline $20-29$ & 67 & 34.359 \\
\hline $30-39$ & 55 & 28.205 \\
\hline $40-49$ & 54 & 27.693 \\
\hline $50-59$ & 15 & 7.692 \\
\hline 60 years $\&$ over & 0 & \\
\hline \multicolumn{3}{|l|}{ Education: } \\
\hline Secondary School \& Lower & 14 & 7.179 \\
\hline Diploma Level & 50 & 25.641 \\
\hline University Graduate & 123 & 63.077 \\
\hline Postgraduate & 8 & 4.103 \\
\hline \multicolumn{3}{|l|}{ Nationality: } \\
\hline Bahraini & 159 & 81.539 \\
\hline Non - Bahraini & 36 & 18.461 \\
\hline \multicolumn{3}{|l|}{ Occupation: } \\
\hline Executive / Manager & 30 & 15.385 \\
\hline Professional & 4 & 2.051 \\
\hline Trade / Proprietor & 21 & 10.769 \\
\hline Student & 26 & 13.333 \\
\hline Craftsman & 8 & 4.103 \\
\hline Retired & 20 & 10.256 \\
\hline Housewife & 25 & 12.821 \\
\hline Unemployment & 6 & 3.077 \\
\hline Others* & 55 & 28.205 \\
\hline Total & 195 & 100 \\
\hline
\end{tabular}

* Others category includes: Teachers, clerks, sellers, air hostess and IT employers.

Table 2. Cronbach's alpha coefficient

\begin{tabular}{|l|c|c|c|}
\hline \multicolumn{1}{|c|}{ Features } & Expectations & Perceptions & P - E \\
\hline Tangibles & .819 & .831 & .739 \\
\hline Reliability & .824 & .882 & .759 \\
\hline Responsiveness & .814 & .853 & .807 \\
\hline Assurance & .825 & .861 & .714 \\
\hline Empathy & .847 & .894 & .788 \\
\hline Total & $\mathbf{. 9 3 5}$ & $\mathbf{. 9 5 6}$ & $\mathbf{. 9 1 4}$ \\
\hline
\end{tabular}


Table 3. Factor loadings for SERQUAL construct

\begin{tabular}{|c|c|c|c|c|c|}
\hline $\begin{array}{r}\text { Dimensions \& } \\
\text { Items } \\
\end{array}$ & Factor 1 & Factor 2 & Factor 3 & Factor 4 & Factor 5 \\
\hline Tangibles & & & & .653 & \\
\hline G1 & & & & .783 & \\
\hline $\mathrm{G} 2$ & & .510 & & .575 & \\
\hline G3 & & & & .701 & \\
\hline G4 & & & & & \\
\hline \multicolumn{6}{|l|}{ Reliability } \\
\hline G5 & & & & .653 & \\
\hline G6 & & & & .658 & \\
\hline G7 & .522 & & & & \\
\hline G8 & & & & .641 & \\
\hline G9 & .511 & & & .517 & \\
\hline \multicolumn{6}{|l|}{ Responsiveness } \\
\hline G10 & .722 & & & & \\
\hline G11 & .674 & & & & \\
\hline G12 & .623 & & & & \\
\hline G13 & .690 & & & & \\
\hline \multicolumn{6}{|l|}{ Assurance } \\
\hline G14 & .519 & & & & \\
\hline G15 & & & .613 & & \\
\hline G16 & & .660 & & & \\
\hline G17 & & & & & .707 \\
\hline \multicolumn{6}{|l|}{ Empathy } \\
\hline G18 & & & & & .629 \\
\hline \multicolumn{6}{|l|}{ G19 } \\
\hline G20 & & .726 & & & \\
\hline G21 & & .709 & & & \\
\hline G22 & & .604 & & & \\
\hline Eigenvalue & 7.935 & 1.646 & 1.615 & 1.204 & 1.021 \\
\hline $\begin{array}{r}\text { Cumulative \% of } \\
\text { variance }\end{array}$ & 36.068 & 43.550 & 50.890 & 56.363 & 61.002 \\
\hline
\end{tabular}


Table 4. Factor loadings for SERPREF construct

\begin{tabular}{|c|c|c|c|}
\hline Dimensions \& Items & Factor 1 & Factor 2 & Factor 3 \\
\hline \multicolumn{4}{|l|}{ Tangibles } \\
\hline 1 & & & .775 \\
\hline 2 & & & .797 \\
\hline 3 & & & .743 \\
\hline 4 & & & .655 \\
\hline \multicolumn{4}{|l|}{ Reliability } \\
\hline 5 & .759 & & \\
\hline 6 & .710 & & \\
\hline 7 & .675 & & \\
\hline 8 & .816 & & \\
\hline 9 & .646 & & \\
\hline \multicolumn{4}{|l|}{ Responsiveness } \\
\hline 10 & .721 & & \\
\hline 11 & .572 & & \\
\hline 12 & .547 & .533 & \\
\hline 13 & & .675 & \\
\hline \multicolumn{4}{|l|}{ Assurance } \\
\hline 14 & .601 & & \\
\hline 15 & .634 & & \\
\hline 16 & .526 & & \\
\hline 17 & .613 & & \\
\hline \multicolumn{4}{|l|}{ Empathy } \\
\hline 18 & & .786 & \\
\hline 19 & & .523 & \\
\hline 20 & & .783 & \\
\hline 21 & & .763 & \\
\hline 22 & & .761 & \\
\hline Eigenvalues & 11.544 & 1.446 & 1.347 \\
\hline $\begin{array}{l}\text { Cumulative \% of } \\
\text { variance }\end{array}$ & 52.742 & 59.042 & 65.166 \\
\hline Cronbach's Alpha & .941 & .911 & .831 \\
\hline
\end{tabular}

Table 5. Relative Importance of Service Quality Dimensions

\begin{tabular}{|c|c|c|c|c|c|}
\hline Factors & $\begin{array}{l}\text { Average } \\
\text { Importance }\end{array}$ & $\begin{array}{l}\text { Weighted } \\
\text { means }\end{array}$ & Beta & $\mathrm{T}$ & Sig \\
\hline Tangible & .204 & 10.2385 & .231 & 4.540 & .000 \\
\hline Reliability & .238 & 12.0513 & .378 & 7.568 & .000 \\
\hline Responsiveness & .208 & 10.2385 & .363 & 7.138 & .000 \\
\hline Assurance & .189 & 9.8462 & .299 & 5.774 & .000 \\
\hline Empathy & .161 & 7.4400 & .287 & 5.675 & .000 \\
\hline $\begin{array}{l}\text { Overall perception } \\
\text { of SQ }\end{array}$ & & $9.9629 *$ & & & \\
\hline R .739 & $\mathrm{R}$ square & & Adjuste & square & \\
\hline $\mathrm{F} \quad 45.354$ & \multicolumn{5}{|c|}{ Significant at 0.05 level } \\
\hline
\end{tabular}


Table 6. The analysis of variance relative to the respondent's gender

ANOVA

\begin{tabular}{|c|c|c|c|c|c|c|}
\hline & & $\begin{array}{l}\text { Sum of } \\
\text { Squares }\end{array}$ & df & Mean Square & $\mathrm{F}$ & Sig. \\
\hline \multirow[t]{3}{*}{ WTAN } & Between Groups & 2.964 & 2 & 1.482 & \multirow[t]{3}{*}{.045} & \multirow[t]{3}{*}{.956} \\
\hline & Within Groups & 6260.198 & 192 & 32.605 & & \\
\hline & Total & 6263.162 & 194 & & & \\
\hline \multirow[t]{3}{*}{ WREL } & Between Groups & 10.436 & 2 & 5.218 & \multirow[t]{3}{*}{.119} & \multirow[t]{3}{*}{.888} \\
\hline & Within Groups & 8429.291 & 192 & 43.903 & & \\
\hline & Total & 8439.727 & 194 & & & \\
\hline \multirow[t]{3}{*}{ WRES } & Between Groups & 62.561 & 2 & 31.281 & \multirow[t]{3}{*}{1.158} & \multirow[t]{3}{*}{.316} \\
\hline & Within Groups & 5188.100 & 192 & 27.021 & & \\
\hline & Total & 5250.662 & 194 & & & \\
\hline \multirow[t]{3}{*}{ WASS } & Between Groups & 7.867 & 2 & 3.933 & \multirow[t]{3}{*}{.151} & \multirow[t]{3}{*}{.860} \\
\hline & Within Groups & 4986.893 & 192 & 25.973 & & \\
\hline & Total & 4994.760 & 194 & & & \\
\hline \multirow[t]{3}{*}{ WEMP } & Between Groups & 7.326 & 2 & 3.663 & \multirow[t]{3}{*}{.203} & \multirow[t]{3}{*}{.816} \\
\hline & Within Groups & 3459.842 & 192 & 18.020 & & \\
\hline & Total & 3467.168 & 194 & & & \\
\hline \multirow[t]{3}{*}{ Overall } & Between Groups & 5.532 & 2 & 2.766 & \multirow[t]{3}{*}{.479} & \multirow[t]{3}{*}{.620} \\
\hline & Within Groups & 1108.770 & 192 & 5.775 & & \\
\hline & Total & 1114.302 & 194 & & & \\
\hline
\end{tabular}

Table 7. The analysis of variance relative to the respondent's age

ANOVA

\begin{tabular}{|ll|r|r|r|r|r|}
\hline & \multicolumn{1}{|c|}{$\begin{array}{c}\text { Sum of } \\
\text { Squares }\end{array}$} & df & Mean Square & F & Sig. \\
\hline WTAN & Between Groups & 66.156 & 4 & 16.539 & .507 & .731 \\
& Within Groups & 6197.005 & 190 & 32.616 & & \\
& Total & 6263.162 & 194 & & & \\
\hline WREL & Between Groups & 56.191 & 4 & 14.048 & .318 & .865 \\
& Within Groups & 8383.537 & 190 & 44.124 & & \\
& Total & 8439.727 & 194 & & & \\
\hline WRES & Between Groups & 60.588 & 4 & 15.147 & .555 & .696 \\
& Within Groups & 5190.074 & 190 & 27.316 & & \\
& Total & 5250.662 & 194 & & & \\
\hline WASS & Between Groups & 83.353 & 4 & 20.838 & .806 & .523 \\
& Within Groups & 4911.407 & 190 & 25.850 & & \\
& Total & 4994.760 & 194 & & & \\
\hline WEMP & Between Groups & 78.745 & 4 & 19.686 & 1.104 & .356 \\
& Within Groups & 3388.423 & 190 & 17.834 & & \\
& Total & 3467.168 & 194 & & & .560 \\
\hline Overall & Between Groups & 17.299 & 4 & 4.325 & .749 & \\
& Within Groups & 1097.003 & 190 & 5.774 & & \\
& Total & 1114.302 & 194 & & & \\
\hline
\end{tabular}


Table 8 . The analysis of variance relative to the respondent's education

ANOVA

\begin{tabular}{|c|c|c|c|c|c|c|}
\hline & & $\begin{array}{l}\text { Sum of } \\
\text { Squares }\end{array}$ & df & Mean Square & $\mathrm{F}$ & Sig. \\
\hline WTAN & $\begin{array}{l}\text { Between Groups } \\
\text { Within Groups } \\
\text { Total }\end{array}$ & $\begin{array}{r}152.289 \\
6110.873 \\
6263.162\end{array}$ & $\begin{array}{r}4 \\
190 \\
194\end{array}$ & $\begin{array}{l}38.072 \\
32.162\end{array}$ & 1.184 & .319 \\
\hline WREL & $\begin{array}{l}\text { Between Groups } \\
\text { Within Groups } \\
\text { Total }\end{array}$ & $\begin{array}{r}143.768 \\
8295.959 \\
8439.727 \\
\end{array}$ & $\begin{array}{r}4 \\
190 \\
194 \\
\end{array}$ & $\begin{array}{l}35.942 \\
43.663\end{array}$ & .823 & .512 \\
\hline WRES & $\begin{array}{l}\text { Between Groups } \\
\text { Within Groups } \\
\text { Total }\end{array}$ & $\begin{array}{r}64.066 \\
5186.596 \\
5250.662\end{array}$ & $\begin{array}{r}4 \\
190 \\
194\end{array}$ & $\begin{array}{l}16.016 \\
27.298\end{array}$ & .587 & .673 \\
\hline WASS & $\begin{array}{l}\text { Between Groups } \\
\text { Within Groups } \\
\text { Total }\end{array}$ & $\begin{array}{r}149.196 \\
4845.564 \\
4994.760\end{array}$ & $\begin{array}{r}4 \\
190 \\
194\end{array}$ & $\begin{array}{l}37.299 \\
25.503\end{array}$ & 1.463 & .215 \\
\hline WEMP & $\begin{array}{l}\text { Between Groups } \\
\text { Within Groups } \\
\text { Total }\end{array}$ & $\begin{array}{r}29.925 \\
3437.243 \\
3467.168 \\
\end{array}$ & $\begin{array}{r}4 \\
190 \\
194 \\
\end{array}$ & $\begin{array}{r}7.481 \\
18.091\end{array}$ & .414 & .799 \\
\hline Overall & $\begin{array}{l}\text { Between Groups } \\
\text { Within Groups } \\
\text { Total }\end{array}$ & $\begin{array}{r}18.880 \\
1095.422 \\
1114.302\end{array}$ & $\begin{array}{r}4 \\
190 \\
194\end{array}$ & $\begin{array}{l}4.720 \\
5.765\end{array}$ & .819 & .515 \\
\hline
\end{tabular}

Table 9. The analysis of variance relative to the respondent's nationality

ANOVA

\begin{tabular}{|ll|r|r|r|r|r|}
\hline & & $\begin{array}{c}\text { Sum of } \\
\text { Squares }\end{array}$ & df & Mean Square & \multicolumn{1}{c|}{$\mathrm{F}$} & \multicolumn{1}{c|}{ Sig. } \\
\hline WTAN & Between Groups & 8.831 & 1 & 8.831 & .273 & .602 \\
& Within Groups & 6254.331 & 193 & 32.406 & & \\
& Total & 6263.162 & 194 & & & \\
\hline WREL & Between Groups & 410.279 & 1 & 410.279 & 9.862 & .002 \\
& Within Groups & 8029.448 & 193 & 41.603 & & \\
& Total & 8439.727 & 194 & & & \\
\hline WRES & Between Groups & 95.835 & 1 & 95.835 & 3.588 & .060 \\
& Within Groups & 5154.826 & 193 & 26.709 & & \\
& Total & 5250.662 & 194 & & & \\
\hline WASS & Between Groups & 52.789 & 1 & 52.789 & 2.062 & .153 \\
& Within Groups & 4941.971 & 193 & 25.606 & & \\
& Total & 4994.760 & 194 & & & .031 \\
\hline WEMP & Between Groups & 82.865 & 1 & 82.865 & 4.726 & \\
& Within Groups & 3384.303 & 193 & 17.535 & & \\
& Total & 3467.168 & 194 & & & \\
\hline Overall & Between Groups & .344 & 1 & .344 & .060 & \\
& Within Groups & 1113.958 & 193 & 5.772 & & \\
& Total & 1114.302 & 194 & & & \\
\hline
\end{tabular}


Table 10. The analysis of variance relative to the respondent's experience

ANOVA

\begin{tabular}{|ll|r|r|r|r|r|}
\hline & \multicolumn{1}{c|}{$\begin{array}{c}\text { Sum of } \\
\text { Squares }\end{array}$} & df & Mean Square & F & Sig. \\
\hline WTAN & Between Groups & 129.235 & 3 & 43.078 & 1.341 & .262 \\
& Within Groups & 6133.926 & 191 & 32.115 & & \\
& Total & 6263.162 & 194 & & & \\
\hline WREL & Between Groups & 221.290 & 3 & 73.763 & 1.714 & .165 \\
& Within Groups & 8218.437 & 191 & 43.028 & & \\
& Total & 8439.727 & 194 & & & \\
\hline WRES & Between Groups & 55.163 & 3 & 18.388 & .676 & .568 \\
& Within Groups & 5195.499 & 191 & 27.202 & & \\
& Total & 5250.662 & 194 & & & \\
\hline WASS & Between Groups & 43.883 & 3 & 14.628 & .564 & .639 \\
& Within Groups & 4950.876 & 191 & 25.921 & & \\
& Total & 4994.760 & 194 & & & \\
\hline WEMP & Between Groups & 231.920 & 3 & 77.307 & 4.564 & .004 \\
& Within Groups & 3235.248 & 191 & 16.938 & & \\
& Total & 3467.168 & 194 & & & \\
\hline Overall & Between Groups & 24.227 & 3 & 8.076 & 1.415 & .240 \\
& Within Groups & 1090.075 & 191 & 5.707 & & \\
& Total & 1114.302 & 194 & & & \\
\hline
\end{tabular}

